DOI: 10.4274/tjh.galenos.2020.2020.0436

Turk J Hematol 2021;38:224-225

\title{
Myeloid Sarcoma Involving the Testicular Vein
}

Testiküler Veni Tutan Myeloid Sarkom

(1) Nuh Filizoğlu, (1) Salih Özgüven

Marmara University Pendik Training and Research Hospital, Clinic of Nuclear Medicine, istanbul, Turkey

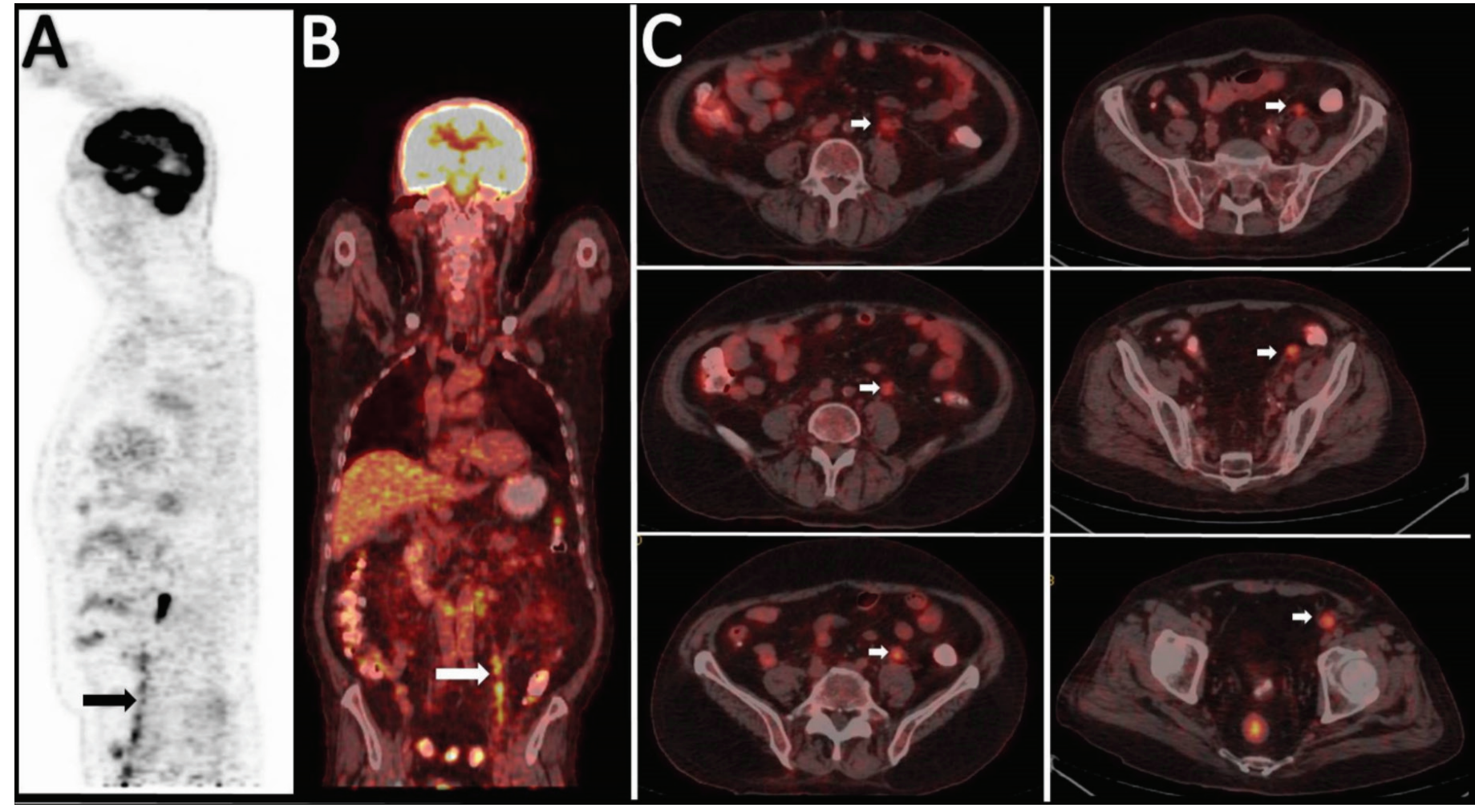

Figure 1. (A-C) F18-FDG PET/CT after left orchiectomy depicted moderate hypermetabolic metastatic retrocrural and paraaortic lymph nodes and multiple intense hypermetabolic foci along the course of the left testicular vein extending up to the left renal vein suggesting testicular vein infiltration of myeloid sarcoma (arrows).

F18-FDG PET/CT: F18-fluorodeoxyglucose positron emission tomography/computed tomography.

A 66-year-old man with a diagnosis of acute myeloid leukemia (AML) type M4 in 2017 who had undergone allogeneic hematopoietic stem cell transplantation in January 2018 presented with painless, nontender left hemiscrotal swelling. The patient underwent unilateral radical orchiectomy and histopathology revealed myeloperoxidase-, CD33-, and CD117positive and CD34-negative infiltration of $A M L$ in the testis and local spread into the spermatic cord, rete testis, epididymis, tunica albuginea, and the surrounding soft tissue suggesting myeloid sarcoma (MS). F18-fluorodeoxyglucose positron emission tomography/computed tomography (FDG PET/CT) after left orchiectomy depicted moderate hypermetabolic metastatic retrocrural and paraaortic lymph nodes and multiple intense hypermetabolic foci along the course of the left testicular 
vein extending up to the left renal vein, suggesting testicular vein infiltration of MS (arrows in Figures $1 \mathrm{~A}-1 \mathrm{C}$ ). MS is a rare neoplasm of leukemic cells that infiltrates extramedullary soft tissue. Testicular involvement of MS is an uncommon entity, especially following hematopoietic stem cell transplantation, and invasion of MS into the spermatic cord and testicular vein is even rarer $[1,2]$. Although FDG PET/CT is well established for detecting, staging, and monitoring response to treatment in MS, this is an extremely rare condition of testicular involvement with invasion of the testicular vein not described before $[3,4]$.

Keywords: Myeloid sarcoma, Testicular vein, Leukemia

Anahtar Sözcükler: Myeloid sarkom, Testiküler ven, Lösemi

Informed Consent: Obtained.

\section{Authorship Contributions}

Concept: S.Ö.; Design: S.Ö.; Data Collection or Processing: N.F.; Analysis or Interpretation: N.F.; Literature Search: N.F.; Writing: N.F.
Conflict of Interest: No conflict of interest was declared by the authors.

Financial Disclosure: The authors declared that this study received no financial support.

\section{References}

1. Almond LM, Charalampakis M, Ford SJ, Gourevitch D, Desai A. Myeloid sarcoma: presentation, diagnosis, and treatment. Clin Lymphoma Myeloma Leuk 2017;17:263-267.

2. Valbuena JR, Admirand JH, Lin P, Medeiros $\amalg$. Myeloid sarcoma involving the testis. Am J Clin Pathol 2005;124:445-452.

3. Stölzel F, Röllig C, Radke J, Mohr B, Platzbecker U, Bornhäuser M, Paulus T, Ehninger G, Zöphel K, Schaich M. ${ }^{18} \mathrm{~F}-\mathrm{FDG}-\mathrm{PET} / \mathrm{CT}$ for detection of extramedullary acute myeloid leukemia. Haematologica 2011;96:15521556.

4. Niu N, Cui R, Li F. FDG PET/CT findings of intracardiac myeloid sarcoma. Clin Nucl Med 2016;41:235-236. 